\title{
Correlation of Impaction of Mandibular Third Molars with Sagittal Dimension of Face
}

\author{
Saugat Ray ${ }^{1}$, Sanjeev Datana ${ }^{2}$, Amit Jain ${ }^{3}$, Mohit Sharma ${ }^{4}$, Prasanna Kumar MP ${ }^{5}$ \\ ${ }^{1}$ Classified Specialist, Department of Orthodontics, NIDS, RC Church, Colaba, Mumbai, ${ }^{2}$ Associate Professor, Department \\ of Dental Surgery and Oral Health Sciences, AFMC, Pune, ${ }^{3}$ Reader and Instructor, Department of Dental Surgery and Oral \\ Health Sciences, AFMC, Pune, ${ }^{4}$ Reader and Instructor, Department of Dental Surgery and Oral Health Sciences AFMC, Pune, \\ ${ }^{5}$ Associate Professor, Department of Dental Surgery and Oral Health Sciences, AFMC, Pune, Maharashtra, India
}

Corresponding author: Sanjeev Datana, Associate Professor, Department of Dental Surgery and Oral Health Sciences, AFMC, Pune, Maharashtra, India

DOI: http://dx.doi.org/10.21276/ijcmsr.2018.3.4.30

How to cite this article: Saugat Ray, Sanjeev Datana, Amit Jain, Mohit Sharma, Prasanna Kumar MP. Correlation of Impaction of mandibular third molars with sagittal dimension of face. International Journal of Contemporary Medicine Surgery and Radiology. 2018;3(4):D131-D136.

\section{A B S T R A C T}

Introduction: The mandibular third molar is one of the most common teeth to get impacted. The etiology of non eruption of mandibular third molar has been attributed to various factors. The present study intends to evaluate the sagittal dimension of facial skeleton of patients with impacted mandibular third molar and their correlation. The aim and objectives of this study was to find out the correlation between various sagittal parameters of face with impaction of mandibular third molar. Material and methods: The radiographs of 66 patients having bilateral impacted mandibular third molars were collected after applying different exclusion and inclusion criteria. Lateral cephalograms were traced and cephalometric parameters were noted. Third molar angulations and retromolar space distal to mandibular third molar were also noted.

Result: The result shows the mean retromolar spaces were significantly lesser in skeletal class III cases compared to class I and II. The mean effective length of mandible was more in skeletal Class III cases and this was statistically significant in comparison to Class I and Class II cases.

Conclusion: The author concludes that the sagittal parameters of maxillary and mandibular region have no correlation with the impaction of mandibular third molars.

Key words: Mandibular Third Molars, Impaction, Growth Pattern, Retromolar Space

\section{INTRODUCTION}

The impaction of mandibular third molars is one of the commonest occurrences and prevalence is comparatively higher than any other teeth. ${ }^{1,2}$ They are also associated with additional complications like carious second or third molars due inappropriate proximal contacts, pericoronitis and even space infections. One of the potential cause of impaction of third molar is deficiency of space between second molars and anterior border of ascending ramus of the mandible. ${ }^{3,4}$ Broadbent and Bjork suggested that the deficient growth potential along with the downward rotation of mandible, to be one of the potential cause of mandibular third molar impaction. ${ }^{3,5}$

Begg studied Australian aboriginal skulls and suggested that, lack of interproximal attrition is one of the factors which attribute to insufficient forward movement of the teeth in modern human beings causing impaction of third molars. ${ }^{6}$ Hence the space gain in alveolar arch facilitated by orthodontic extraction of premolars or extraction of second molars have shown to increase the eruption space which in turn results in decreased frequency of mandibular and maxillary third molars getting impacted. ${ }^{7,8}$
Individuals with brachyfacial pattern shows two times lower incidence of third-molar impaction compared to subjects with dolichofacial growth pattern. ${ }^{9}$ Kaplan $^{10}$ found larger mandibular plane angles in patients with impacted mandibular third molars compared to the cases with erupted third molars. Richardson ${ }^{11}$, in a longitudinal study observed significant number of third molar impactions in cases of skeletal Class II malocclusion with smaller mandibular dimensions.

Although the general concepts of growth of human skull along with its effects on eruption pattern especially on mandibular third molars has been explained by various authors but these are simultaneously affected by various other factors like ethnicity, race and change of geographical locations. ${ }^{12,13}$

The present study intends to find out the fact that, does skeletal dimensions of maxillomandibular region have impact on the non eruption of mandibular third molar and hence casing impaction or mere the retromolar space inadequacy is responsible for mandibular third molar to get impacted. The study had been split into two parts. The first and the present part focuses on the sagittal dimensions of face and in the second part, the vertical dimensions of the face were 
considered.

The aim and objectives of this part of study was to find out the correlation of various sagittal parameters of maxillo mandibular region with impaction of mandibular third molar.

\section{MATERIAL AND METHODS}

The sample for this multicentric cross sectional study was collected from the archives of orthodontic clinics of three major academic institutions. The Orthopantomogram and Lateral cephalogram of all the patients who attended the clinic for orthodontic treatment in last three years were collected. All the cases of bilaterally impacted lower molar were collected as initial sample. The following inclusion and exclusion criteria were applied

\section{Inclusion criteria}

1. Bilaterally impacted lower third molars.

2. Patients with age $>18$ yrs

\section{Exclusion criteria}

1. Patients with craniofacial anomaly or syndromes
2. Presence of any other impacted teeth

3. Patients with history of previous Orthodontic treatment. After Applying all the inclusion and exclusion criteria 66 cases were selected for the study. The lateral cephalogram of these 66 patients served as study samples. The cephalogram were retraced manually by two orthodontists including the authors for validity of the cephalometric measurements. The space available for third molar was calculated from the linear distance parallel to occlusal plane between distal surface of the second molar and J point (Fig 1). The J point was created at the intersection of occlusal plane with the anterior border of ramus of the mandible. The mesio distal width of the mandibular third molars was also measured. The adequacy of space available for third molar was calculated to rule out any other factors causing the impaction of third molars. Third molar angulations were measured as anterior angle between long axis of the impacted third molar and mandibular plane from Gonion to Menton (Fig 1).

The sagittal parameters considered for the study were Steiners analysis, Mc Namara analysis and the linear measurements

\begin{tabular}{|c|c|c|c|c|c|c|c|c|c|}
\hline & & \multirow[t]{2}{*}{$\mathbf{N}$} & \multirow[t]{2}{*}{ Mean } & \multirow{2}{*}{$\begin{array}{c}\text { Std. } \\
\text { Devia- } \\
\text { tion }\end{array}$} & \multirow[t]{2}{*}{$\begin{array}{l}\text { Std. } \\
\text { Error }\end{array}$} & \multicolumn{2}{|c|}{$\begin{array}{l}\text { 95\% Confidence } \\
\text { Interval for Mean }\end{array}$} & \multirow[t]{2}{*}{$\begin{array}{l}\text { Mini- } \\
\text { mum }\end{array}$} & \multirow[t]{2}{*}{$\begin{array}{l}\text { Maxi- } \\
\text { mum }\end{array}$} \\
\hline & & & & & & $\begin{array}{l}\text { Lower } \\
\text { Bound }\end{array}$ & $\begin{array}{l}\text { Upper } \\
\text { Bound }\end{array}$ & & \\
\hline \multirow[t]{4}{*}{ Ef Length Max } & Class-1 & 24 & 93.6667 & .90490 & .18471 & 93.2846 & 94.0488 & 92.00 & 95.00 \\
\hline & Class-II & 35 & 93.7571 & 2.50403 & .42326 & 92.8970 & 94.6173 & 90.00 & 98.00 \\
\hline & Class-III & 7 & 89.2143 & 1.25357 & .47380 & 88.0549 & 90.3736 & 87.50 & 91.00 \\
\hline & Total & 66 & 93.2424 & 2.38141 & .29313 & 92.6570 & 93.8278 & 87.50 & 98.00 \\
\hline \multirow[t]{4}{*}{ Ef Length Mand } & Class-1 & 24 & 1.1517E2 & 1.72996 & .35313 & 114.4362 & 115.8972 & 112.00 & 118.00 \\
\hline & Class-II & 35 & $1.1303 \mathrm{E} 2$ & 4.31813 & .72990 & 111.5452 & 114.5119 & 104.50 & 122.00 \\
\hline & Class-III & 7 & $1.2321 \mathrm{E} 2$ & 2.05866 & .77810 & 121.3103 & 125.1182 & 119.50 & 126.00 \\
\hline & Total & 66 & 1.1489E2 & 4.53431 & .55813 & 113.7717 & 116.0010 & 104.50 & 126.00 \\
\hline \multirow[t]{4}{*}{ Max Mand Differential } & Class-1 & 24 & 21.5000 & 2.23607 & .45644 & 20.5558 & 22.4442 & 17.50 & 25.00 \\
\hline & Class-II & 35 & 19.3857 & 5.13936 & .86871 & 17.6203 & 21.1511 & 11.00 & 28.00 \\
\hline & Class-III & 7 & 34.0000 & 2.76887 & 1.04654 & 31.4392 & 36.5608 & 30.00 & 37.00 \\
\hline & Total & 66 & 21.7045 & 5.95688 & .73324 & 20.2402 & 23.1689 & 11.00 & 37.00 \\
\hline \multirow[t]{4}{*}{ Pog to $N$ perp } & Class-1 & 24 & .5417 & 1.58743 & .32403 & -.1286 & 1.2120 & -3.00 & 2.50 \\
\hline & Class-II & 35 & -1.3429 & 1.57542 & .26629 & -1.8840 & -.8017 & -5.00 & 1.50 \\
\hline & Class-III & 7 & 3.3286 & 1.89887 & .71771 & 1.5724 & 5.0847 & 1.30 & 6.00 \\
\hline & Total & 66 & -.1621 & 2.18370 & .26879 & -.6989 & .3747 & -5.00 & 6.00 \\
\hline \multirow[t]{4}{*}{ A to $N$ perp } & Class-1 & 24 & -.1250 & 1.08598 & .22167 & -.5836 & .3336 & -1.50 & 2.00 \\
\hline & Class-II & 35 & 1.5571 & 1.33269 & .22526 & 1.0993 & 2.0149 & -1.00 & 4.00 \\
\hline & Class-III & 7 & .1429 & 1.54689 & .58467 & -1.2878 & 1.5735 & -2.00 & 2.50 \\
\hline & Total & 66 & .7955 & 1.49609 & .18416 & .4277 & 1.1632 & -2.00 & 4.00 \\
\hline \multirow[t]{4}{*}{ Mand Length (Go to Pog) } & Class-1 & 24 & 84.6042 & 1.91095 & .39007 & 83.7972 & 85.4111 & 81.00 & 88.50 \\
\hline & Class-II & 35 & 84.0286 & 2.49394 & .42155 & 83.1719 & 84.8853 & 78.50 & 88.00 \\
\hline & Class-III & 7 & 86.1429 & 2.07594 & .78463 & 84.2229 & 88.0628 & 82.50 & 88.50 \\
\hline & Total & 66 & 84.4621 & 2.31435 & .28488 & 83.8932 & 85.0311 & 78.50 & 88.50 \\
\hline \multirow{4}{*}{$\begin{array}{l}\text { Third molar } \\
\text { Angulations }\end{array}$} & Class-1 & 24 & 79.9167 & 12.32148 & 2.51511 & 74.7138 & 85.1196 & 38.00 & 95.00 \\
\hline & Class-II & 35 & 77.0429 & 10.56379 & 1.78561 & 73.4141 & 80.6716 & 55.00 & 96.00 \\
\hline & Class-III & 7 & 77.2857 & 4.95696 & 1.87355 & 72.7013 & 81.8701 & 68.00 & 82.00 \\
\hline & Total & 66 & 78.1136 & 10.78203 & 1.32718 & 75.4631 & 80.7642 & 38.00 & 96.00 \\
\hline \multirow[t]{4}{*}{ Retromolar space Discrepancy } & Class-1 & 24 & -1.7500 & 1.66812 & .34050 & -2.4544 & -1.0456 & -4.50 & 2.00 \\
\hline & Class-II & 35 & -1.8857 & 2.33920 & .39540 & -2.6893 & -1.0822 & -6.00 & 3.00 \\
\hline & Class-III & 7 & -5.1429 & 7.54274 & 2.85089 & -12.1187 & 1.8330 & -22.00 & -.50 \\
\hline & Total & 66 & -2.1818 & 3.18728 & .39233 & -2.9653 & -1.3983 & -22.00 & 3.00 \\
\hline
\end{tabular}




\begin{tabular}{|c|c|c|c|c|c|c|}
\hline & & Sum of Squares & df & $\begin{array}{l}\text { Mean } \\
\text { Square }\end{array}$ & $\mathbf{F}$ & Sig. \\
\hline \multirow[t]{3}{*}{ Ef Length Max } & Between Groups & 127.174 & 2 & 63.587 & 16.591 & .000 \\
\hline & Within Groups & 241.448 & 63 & 3.833 & & \\
\hline & Total & 368.621 & 65 & & & \\
\hline \multirow[t]{3}{*}{ Ef Length Mand } & Between Groups & 608.164 & 2 & 304.082 & 26.306 & .000 \\
\hline & Within Groups & 728.233 & 63 & 11.559 & & \\
\hline & Total & 1336.398 & 65 & & & \\
\hline \multirow[t]{3}{*}{ Max Mand Differential } & Between Groups & 1247.446 & 2 & 623.723 & 37.104 & .000 \\
\hline & Within Groups & 1059.043 & 63 & 16.810 & & \\
\hline & Total & 2306.489 & 65 & & & \\
\hline \multirow[t]{3}{*}{ Pog to $\mathrm{N}$ perp } & Between Groups & 145.977 & 2 & 72.988 & 28.042 & .000 \\
\hline & Within Groups & 163.978 & 63 & 2.603 & & \\
\hline & Total & 309.955 & 65 & & & \\
\hline \multirow{3}{*}{ A to $N$ perp } & Between Groups & 43.621 & 2 & 21.810 & 13.489 & .000 \\
\hline & Within Groups & 101.868 & 63 & 1.617 & & \\
\hline & Total & 145.489 & 65 & & & \\
\hline \multirow[t]{3}{*}{ Mand Length (Go to Pog) } & Between Groups & 26.837 & 2 & 13.419 & 2.631 & .080 \\
\hline & Within Groups & 321.318 & 63 & 5.100 & & \\
\hline & Total & 348.155 & 65 & & & \\
\hline \multirow[t]{3}{*}{ Third molar Angulations } & Between Groups & 122.950 & 2 & 61.475 & .521 & .596 \\
\hline & Within Groups & 7433.448 & 63 & 117.991 & & \\
\hline & Total & 7556.398 & 65 & & & \\
\hline \multirow[t]{3}{*}{ Retromolar space Discrepancy } & Between Groups & 68.918 & 2 & 34.459 & 3.671 & .031 \\
\hline & Within Groups & 591.400 & 63 & 9.387 & & \\
\hline & Total & 660.318 & 65 & & & \\
\hline
\end{tabular}

of mandible (Gonion to Menton). The data was compiled and statistical analysis was done.

\section{STATISTICAL ANALYSIS}

The data collected was processed in excel sheet and was statistically analyzed using computer software package SPSS ver. 16 (SPSS Inc, Chicago, III). One way ANOVA test was applied with 95\% confidence interval and various sagittal parameters were analyzed for different skeletal types. The $\mathrm{P}$ value was set with a significance level of 0.05 . Multiple comparison analysis was carried out using Post Hoc test (Table 2 and 3).

Various sagittal parameters studied were compared among three skeletal classes. The statistical evaluation reveals that the differences between retromolar spaces in skeletal class I and Class II is statistically not significant where as in skeletal Class III cases the lesser retromolar spaces were found to be statistically significant when compared to skeletal Class I and Class II, with p value being 0.032 and 0.033 respectively. The mean effective length of mandible as per Mc Namara analysis and body length (Go-Pog) in cases of skeletal Class III is $123.21 \mathrm{~mm}$ and $86.14 \mathrm{~mm}$ respectively which is higher than both Class I and Class II groups and also the difference was found to be statistically highly significant. Although mean third molar angulations in skeletal Class I was higher than both Class II and Class III but the differences were not found to be statistically significant (Table 1,2 and 3).

\section{RESULTS}

Among the total 66 lateral cephalograms traced, 53.03\%

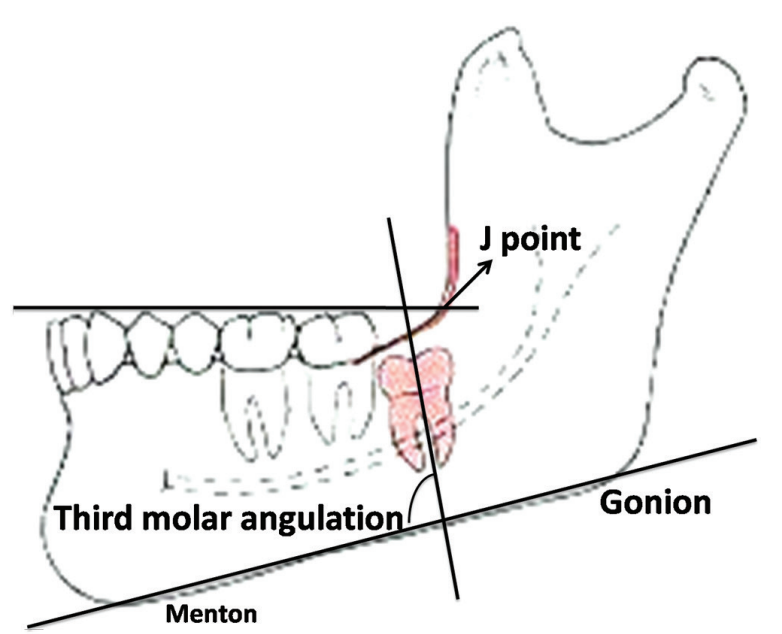

Figure-1:

of patients were skeletally Class II, followed by Class I (36.36\%) and least were skeletally Class III (10.60\%) (Table 1). The total study sample had $87.87 \%$ of patients who had inadequate retromolar space to accommodate the third molars. The balance cases had either mesioangular impaction (9.09\%) or horizontal impaction (3.03\%), causing relative inadequacy of space due to inappropriate path of eruption. The mean length of body of mandible as measured from Gonion to pogonion for all cases were within normal limits as suggested by Burstone ${ }^{12}$ (Table 1 ).

\section{DISCUSSION}

A mandibular third molar is the last tooth to erupt in the 


\begin{tabular}{|c|c|c|c|c|c|c|c|}
\hline \multicolumn{8}{|l|}{ Tukey HSD } \\
\hline \multirow[t]{2}{*}{ Dependent Variable } & \multirow[t]{2}{*}{ (I) group } & \multirow{2}{*}{$\begin{array}{c}\text { (J) } \\
\text { group }\end{array}$} & \multirow{2}{*}{$\begin{array}{c}\text { Mean } \\
\text { Difference } \\
(1-J)\end{array}$} & \multirow[t]{2}{*}{ Std. Error } & \multirow[t]{2}{*}{ Sig. } & \multicolumn{2}{|c|}{ 95\% Confidence Interval } \\
\hline & & & & & & $\begin{array}{l}\text { Lower } \\
\text { Bound }\end{array}$ & $\begin{array}{l}\text { Upper } \\
\text { Bound }\end{array}$ \\
\hline \multirow[t]{6}{*}{ Ef Length max } & \multirow[t]{2}{*}{ Class-1 } & Class-II & -.09048 & .51883 & .983 & -1.3358 & 1.1549 \\
\hline & & Class-III & $4.45238^{*}$ & .84094 & .000 & 2.4338 & 6.4709 \\
\hline & \multirow[t]{2}{*}{ Class-II } & Class-1 & .09048 & .51883 & .983 & -1.1549 & 1.3358 \\
\hline & & Class-III & $4.54286^{*}$ & .81056 & .000 & 2.5973 & 6.4885 \\
\hline & \multirow[t]{2}{*}{ Class-III } & Class-1 & $-4.45238^{*}$ & .84094 & .000 & -6.4709 & -2.4338 \\
\hline & & Class-II & $-4.54286^{*}$ & .81056 & .000 & -6.4885 & -2.5973 \\
\hline \multirow[t]{6}{*}{ Ef Length mand } & \multirow[t]{2}{*}{ Class-1 } & Class-II & 2.13810 & .90106 & .053 & -.0247 & 4.3009 \\
\hline & & Class-III & $-8.04762^{*}$ & 1.46047 & .000 & -11.5532 & -4.5420 \\
\hline & \multirow[t]{2}{*}{ Class-II } & Class-1 & -2.13810 & .90106 & .053 & -4.3009 & .0247 \\
\hline & & Class-III & $-10.18571^{*}$ & 1.40769 & .000 & -13.5646 & -6.8068 \\
\hline & \multirow[t]{2}{*}{ Class-III } & Class-1 & $8.04762^{*}$ & 1.46047 & .000 & 4.5420 & 11.5532 \\
\hline & & Class-II & $10.18571^{*}$ & 1.40769 & .000 & 6.8068 & 13.5646 \\
\hline \multirow[t]{6}{*}{ Max- Mand Differential } & \multirow[t]{2}{*}{ Class-1 } & Class-II & 2.11429 & 1.08661 & .134 & -.4939 & 4.7225 \\
\hline & & Class-III & $-12.50000^{*}$ & 1.76122 & .000 & -16.7275 & -8.2725 \\
\hline & \multirow[t]{2}{*}{ Class-II } & Class-1 & -2.11429 & 1.08661 & .134 & -4.7225 & .4939 \\
\hline & & Class-III & $-14.61429^{*}$ & 1.69757 & .000 & -18.6890 & -10.5396 \\
\hline & \multirow[t]{2}{*}{ Class-III } & Class-1 & $12.50000^{*}$ & 1.76122 & .000 & 8.2725 & 16.7275 \\
\hline & & Class-II & $14.61429^{*}$ & 1.69757 & .000 & 10.5396 & 18.6890 \\
\hline Pog- N- perp & Class-1 & Class-II & $1.88452^{*}$ & .42757 & .000 & .8582 & 2.9108 \\
\hline & & Class-III & $-2.78690^{*}$ & .69303 & .000 & -4.4504 & -1.1234 \\
\hline & Class-II & Class-1 & $-1.88452^{*}$ & .42757 & .000 & -2.9108 & -.8582 \\
\hline & & Class-III & $-4.67143^{*}$ & .66798 & .000 & -6.2748 & -3.0681 \\
\hline & Class-III & Class-1 & $2.78690^{*}$ & .69303 & .000 & 1.1234 & 4.4504 \\
\hline & & Class-II & $4.67143^{*}$ & .66798 & .000 & 3.0681 & 6.2748 \\
\hline A to $N$ perp & Class-1 & Class-II & $-1.68214^{*}$ & .33700 & .000 & -2.4911 & -.8732 \\
\hline & & Class-III & -.26786 & .54623 & .876 & -1.5790 & 1.0433 \\
\hline & Class-II & Class-1 & $1.68214^{*}$ & .33700 & .000 & .8732 & 2.4911 \\
\hline & & Class-III & $1.41429^{*}$ & .52649 & .025 & .1505 & 2.6780 \\
\hline & Class-III & Class-1 & .26786 & .54623 & .876 & -1.0433 & 1.5790 \\
\hline & & Class-II & $-1.41429^{*}$ & .52649 & .025 & -2.6780 & -.1505 \\
\hline Mand Length & Class-1 & Class-II & .57560 & .59853 & .604 & -.8611 & 2.0123 \\
\hline (Go-Pog) & & Class-III & -1.53869 & .97012 & .259 & -3.8673 & .7899 \\
\hline & Class-II & Class-1 & -.57560 & .59853 & .604 & -2.0123 & .8611 \\
\hline & & Class-III & -2.11429 & .93506 & .069 & -4.3587 & .1302 \\
\hline & Class-III & Class-1 & 1.53869 & .97012 & .259 & -.7899 & 3.8673 \\
\hline & & Class-II & 2.11429 & .93506 & .069 & -.1302 & 4.3587 \\
\hline Third molar Angulations & Class-1 & Class-II & 2.87381 & 2.87880 & .581 & -4.0362 & 9.7839 \\
\hline & & Class-III & 2.63095 & 4.66607 & .840 & -8.5691 & 13.8310 \\
\hline & Class-II & Class-1 & -2.87381 & 2.87880 & .581 & -9.7839 & 4.0362 \\
\hline & & Class-III & -.24286 & 4.49745 & .998 & -11.0382 & 10.5525 \\
\hline & Class-III & Class-1 & -2.63095 & 4.66607 & .840 & -13.8310 & 8.5691 \\
\hline & & Class-II & .24286 & 4.49745 & .998 & -10.5525 & 11.0382 \\
\hline Retromolar space Discrepancy & Class-1 & Class-II & .13571 & .81200 & .985 & -1.8134 & 2.0848 \\
\hline & & Class-III & $3.39286^{*}$ & 1.31612 & .032 & .2337 & 6.5520 \\
\hline & Class-II & Class-1 & -.13571 & .81200 & .985 & -2.0848 & 1.8134 \\
\hline & & Class-III & $3.25714^{*}$ & 1.26856 & .033 & .2122 & 6.3021 \\
\hline & Class-III & Class-1 & $-3.39286^{*}$ & 1.31612 & .032 & -6.5520 & -.2337 \\
\hline & & Class-II & $-3.25714^{*}$ & 1.26856 & .033 & -6.3021 & -.2122 \\
\hline
\end{tabular}

oral cavity and usually poses lots of problems in most of the cases. They frequently get impacted due to space inadequacy, altered or unfavorable path of eruption, ectopic positions of teeth and hard and soft tissue obstructions. It is because of 
associated periodontal pathologies and other complications associated with $i^{14,15}$, the etiology and the various factors affecting non eruption of mandibular third molars needs to be identified.

The samples for this study comprised of radiographs of patients from different geographical areas of India hence the ethnic factor has been ruled out at the beginning of the study. As discussed earlier, the study was divided in two parts with the present part primarily focusing on the correlation between sagittal dimensions of maxillo mandibular region and impaction of mandibular third molar.

The present study reveals the highest prevalence of impacted third molars in skeletal class II cases compared to class I and III. Few authors ${ }^{9}$ suggested that the brachycephalic faces had higher prevalence of increase space distal for full eruption of mandibular third molar which is not in consensus with the present study. Although the study samples for the present study were lesser in comparison to the previous study due to limitations of the lack of adequate samples in archives, but still the present study reveals that $100 \%$ samples of skeletal class III malocclusion patients had inadequate retromolar space available for the eruption of mandibular third molar.

Few studies in past had also tried to associate the mandibular body length with the impaction of mandibular third molars. ${ }^{3,11,16}$ They suggested the attributability of short mandibular body length with impaction of third molars. Contrary to this, Kaplan and Dierkes did not found significant correlation between mandibular length and impacted mandibular third molars. ${ }^{17,18}$ Despite of the fact that $100 \%$ sample had bilaterally impacted third molars, the mean length of body of mandible as measured from Gonion to pogonion for all cases were within normal limits as suggested by Burstone ${ }^{12}$ (Table 1). The present study is in agreement to the studies by Kaplan and Dierkes. Despite of increased body length in skeletal class III cases the mean retromolar space deficiency in Class III cases is significantly higher than the other two groups.

Further, despite of lesser mean effective length of the mandible in skeletal Class II cases compared Class I which is statistically significant also, the retromolar space deficiency between these two groups were statistically insignificant. Hence the present study does not suggest any attributability of mandibular length to the retromolar space deficiency causing impaction of third molar.

Few authors ${ }^{19,20}$ had suggested that inadequate space in the retromolar region as the primary cause of the impaction of mandibular third molar, which is also supported by the present study. Although few cases in the present study were found to have adequate space, but the inappropriate angulations of third molars were impeding the path of eruption of the teeth.

\section{CONCLUSION}

Although in present study, the impaction of third molars were more prevalent in skeletal class II but further analysis of cephalometric parameters suggests that the sagittal dimensions of face cannot be made attributable to the impactions of mandibular third molar. Its only the absolute or relative deficiency of retromolar spaces distal to mandibular third molar which decides the eruption pattern of mandibular third molars. The relative deficiencies were due to improper angulations of the mandibular third molar or abnormal path of eruption.

Hence it is concluded that the sagittal dimensions of maxillo mandibular region does not have any correlation with the impaction of mandibular third molar.

\section{REFERENCES}

1. Bishara SE, Andreason G. Third molars: a review. Am J Orthod 1983; 83(4):131-137.

2. Andreasen, J.O., 1997. In: Andreasen, J.O., Peterson, J.K., Laskin, D.M. (Eds.), Textbook and Color Atlas of Tooth Impactions. Munksgaard, Copenhagen, pp. 222-223.

3. Bjork A, Jensen E, Palling M. Mandibular growth and third molar impaction. Acta Odont Scand 1956; 14 (1):231-271.

4. Shilling G. Development and eruption of the mandibular third molar and its response to orthodontic therapy. Angle Orthod 1973; 43 (2):271-278.

5. Broadbent BH. The influence of the third molars on the alignment of teeth. Am J Orthod 1943; 29:312-330.

6. Begg PR. Stone Age man's dentition. Am J Orthod 1954; 40 (4): 298-312.

7. Gooris CGM, Artun J, Joondeph DR. Eruption of mandibular third molars after second molar extractions: a radiographic study. Am J Orthod Dentofacial Orthop 1990;98 (1):161-167.

8. Kim T, A ${ }^{\circ}$ rtun J, Behbehani F, Artese F. Prevalence of third molar impaction in orthodontic patients treated non-extraction and with extraction of 4 premolars. Am J Orthod Dentofacial Orthop 2003; 123 (5):138-145.

9. Breik, O., Grubor, D. The incidence of mandibular third molar impactions in different skeletal face types. Aust Dent J. 2008;53 (4): 320- 324.

10. Kaplan RG. Some factors related to mandibular third molar impaction. Angle Orthod 1975; 45 (1): 153-158.

11. Richardson ME. The etiology and prediction of mandibular third molar impaction. Angle Orthod 1977; 47 (3): 165-172.

12. Burstone CJ, james RB, Legan H, Murphy GA, Norton LA. Cephalometrics for orthognathic surgery. J oral Surg 1978;36(4): 269-77.

13. Hassan AH. Mandibular cephalometric characteristics of a Saudi sample of patients having impacted third molars. Saudi Dent J. 2011; 23(2): 73-80.

14. Eliasson S, Heimdahl A, Nordenram A. Pathological changes related to long-term impaction of third molars. A radiographic study. Int J Oral Maxillofac Surg 1989; 18 (2): 210-12.

15. Elter JR, Offenbacher S, White RP, Beck JD. Third molars associated with periodontal pathology in older Americans. J Oral Maxillofac Surg 2005; 63 (1): 179-84.

16. Ricketts RM. Studies leading to the practice of abortion of lower third molars. Dent Clin N Am 1979; 23 (5):393-411.

17. Kaplan RG. Some factors related to mandibular third molar impaction. Angle Orthod 1975; 45 (6):153-158.

18. Dierkes DD. An investigation of the mandibular third molars in orthodontic cases. Angle Orthod 1975; 45 (3):207-212. 
19. Olive R, Basford K Reliability and validity of lower third molar space-assessment techniques. Am J Orthod 1981; 79 (4): 45-54.

20. Uthman A T. Retromolar space analysis in relation to selected linear and angular measurements for an Iraqi sample. Oral Surg Oral Med Oral Pathol Oral Radiol Endod 2007; 104 (1): e76-e82.

Source of Support: Nil; Conflict of Interest: None

Submitted: 22-11-2018; Accepted: 20-12-2018; Published online: 02-01-2019 